Original Article

\title{
The Expression of HBME1, PAX8, CD56 and CITED1 in Benign Lesions, Benign and Malignant Tumors of Thyroid
}

\section{Tiroidin Benign Lezyonları, Benign ve Malign Tümörlerinde HBME1, PAX8, CD56 ve CITED1 Ekspresyonun Değerlendirilmesi}

\author{
Gamze Erkılınç ${ }^{1}$, Sezer Kulaçoğlu ${ }^{2}$ \\ ${ }^{1}$ Department of Pathology University of Süleyman Demirel, Isparta \\ ${ }^{2}$ Ankara City Hospital, Department of Pathology, Ankara
}

\begin{abstract}
Introduction: To evaluate the role of HBME1, PAX8, CD56 and CITED1 in distunguishing benign lesions of the thyroid from malignant tumors and different malignant tumors of the thyroid.

Methods: The patients that underwent thyroidectomy between 2007 and 2013 were included to the study. Patients with Nodular Hyperplasia: 22, Folicular Adenoma: 14, Noninvasive Folicular Thyroid Neoplasm With Papillary-Like Nuclear Features: 3, Well Diferentiated Carcinoma, Not Otherwise Specified: 3, Papillary Carcinoma: 22, Papillary Carcinoma Folicular Variant: 12, Minimally Invasive Folicular Carcinoma: 9, Poorly Diferentiated Carcinoma: 4, Anaplastic Carcinoma: 3 were included to the study. HBME1, CITED1, PAX8, CD56 were applied by immunohistochemical method. In statistical analysis, the sensitivity, specificity, positive predictive and negative predictive values of markers were calculated.

Results: CD56 (loss of expression), HBME1 was significantly higher in Papillary Carcinoma, Papillary Carcinoma Folicular Variant compared to other malignant neoplasms. The most sensitive markers for malignant tumors were PAX8 and CITED1 $(90 \%, 88 \%)$. The most specific markers for malignant tumors were HBME1, CITED1 (97\%, 92\%). The most sensitive and specific marker for Papillary Carcinoma, Papillary Carcinoma Folicular Variant was HBME1 (100\%, 80\%). CD56 (loss of expression), CITED1 was the most sensitive markers for Papillary Carcinoma Folicular Variant (86\%, $86 \%)$.

Discussion and conclusion: HBME1 was found an both sensititive and specific marker for Papillary Carcinoma. The cytoplasmic expression of CITED1 was significantly higher in PC compared to other malignant tumors. Nuclear expression of PAX8 was found significantly higher in benign cases compared to malignant tumors. HBME1, CD56 (loss of expression) was found significantly higher in Papillary Carcinoma, Papillary Carcinoma Folicular Variant compared to other malignant tumors.
\end{abstract}

Keywords: Thyroid, HBME1, CITED1, CD56, PAX8

\section{ÖZET}

Giriş ve amaç: HBME1, PAX8, CD56 ve CITED1' in tiroidin benign lezyonlarını, malign tümörlerden ve tiroidin farklı malign tümörlerini birbirinden ayırt etmedeki rolünü değerlendirmektir.

Yöntem ve gereçler: 2007-2013 yılları arasında tiroidektomi yapılan Nodüler Hiperplazi: 22, Foliküler Adenoma: 14, Papiller Benzeri Nükleer Özellikler Gösteren non-İnvaziv Foliküler Tiroid Neoplazmı: 3, İyi Diferansiye Karsinoma, Spesifiye Edilememiş: 3, Papiller Karsinoma: 22, Papiller Karsinoma, Foliküler Varyant: 12, Minimal İnvaziv Foliküler Karsinoma: 9, Az Diferansiye Karsinoma: 4, Anaplastik Karsinoma: 3 çalışmaya dahil edildi. İmmünhistokimyasal yöntem ile HBME1, CITED1, PAX8, CD56 uygulandı. İstatistiksel analizde markerlerın duyarlılık, özgüllük, pozitif ve negatif prediktif değerleri hesaplandi.

Bulgular: CD56 (ekspresyon kaybı), HBME1, Papiller Karsinoma ve Papiller Karsinoma, Foliküler Varyantta, diğer malign tümörlere göre anlamlı yüksekti. Malign tümörler için en duyarlı markerlar PAX8 ve CITED1 (\%90, \%88) idi. Malign tümörler için en spesifik markerlar HBME1, CITED1 (\%97, 
\%92)idi. Papiller Karsinoma, Papiller Karsinoma, Foliküler Varyant için en duyarlı ve spesifik marker HBME1 (\%100, \%80) idi. Papiller Karsinoma, Folliküler Varyant için en duyarlı markerlar CD56 (ekspresyon kayb1) ve CITED1 (\%86, \%86)idi.

Tartışma ve sonuç: HBME1, Papiller Karsinoma için duyarlı ve spesifik bulundu. CITED1'in sitoplazmik ekspresyonun Papiller Karsinomada, tiroidin diğer malign tümörlerine göre anlamlı şekilde yüksekti. PAX8'in nükleer ekspresyonu benign olgularda malign olgulara göre anlamlı şekilde yüksek bulundu. HBME1, CD56 (ekspresyon kaybı), Papiller Karsinoma ve Papiller Karsinoma, Foliküler Varyantta diğer malign tümörlere göre anlamlı şekilde yüksek bulundu.

Anahtar Kelimeler: Tiroid, HBME1, CITED1, CD56, PAX8

\section{Introduction}

Palpable thyroid nodules were reported to occur in 5-10\% of the population [1]. Most of the thyroid nodules are hyperplastic nodules and folicular adenoma and only $2-5 \%$ of them are malignant tumors [1].

The characteristic features for different thyroid neoplasm are specific nuclear pattern for papillary thyroid cancer, invasive pattern for folicular cancer, neuroendocrine features for medullary carcinoma, necrosis and nuclear pleomorphism for poor differentiated carcinoma, high mitosis and anaplastic features for indifferentiated carcinoma. Noninvasive folicular thyroid neoplasm with papillary-like nuclear features (NIFTP) is a new definition of which is suspicious of papillary carcinoma and has no capsule and vascular invasion. Although morphological features are of choice, immunohistochemistry as an ancillary method may be useful in diagnosis of folicular neoplasms.

The fact that the diagnosis will significantly affect the patient's treatment process and prognosis makes this differential diagnosis problem even more critical. Therefore, immunohistochemical markers were searched to contribute to the differential diagnosis of thyroid nodules.

Hector Battifora Mesothelial-1 (HBME1) is a monoclonal antibody for malignant epithelial mesothelioma cells. The expression of HBME1 was shown in papillary and folicular thyroid carcinoma. However expression of HBME1 in normal thyroid tissue was not shown [2]. Cbp/p300 Interacting Transactivator (CITED) proteins are known to regulate nuclear transcription factors. The expression of CITED1 was shown in breast epithelial cells and testicular germ cells. CITED1 can be used in differentiate from papillary thyroid carcinoma and benign thyroid lesions [3]. Paired box-8 (PAX8) is an important gene in thyroid embryogenesis. PAX8 expression has been demonstrated in mullerian, renal and upper urinary tract carcinoma and a sensitive marker for thyroid tumors [4, 5]. CD56 effects migratuar capacity of tumoral cells. Expression of CD56 was reported to be useful in differeanting folicular neoplasms or papillary thyroid carcinoma [4].

Our aim was to evaluate the performance of HBME1, PAX8, CD56, and CITED1 in differantiating benign cases and malignant thyroid tumors and evaluate subtypes of different malignant thyroid tumors.

\section{Materials and Methods}

Patient Selection and Design

After approval of instutitional review board (Ethics Comitee 511/2013) the patients that underwent thyroidectomy between 2007 ve 2013 were included to the study. As the study was retrospective no informed consent was obtained. The distrubution of the pathologic diagnosis were as follows; Nodular Hyperplasia (NH): 22, Folicular Adenoma (FA): 14, Noninvasive Folicular Thyroid Neoplasm with Papillary-Like Nuclear Features (NIFTP): 3, Well Diferentiated Carcinoma, Not Otherwise Specified (WDCNOS): 3, Papillary Carcinoma (PC): 22, Papillary Carcinoma Folicular Variant (PCFV): 12, Minimally Invasive Folicular Carcinoma (MIFC): 9, Poorly Diferentiated Carcinoma (PDC): 4, Anaplastic Carcinoma 
(AC): 3 were included to the study. The collected data were histopathologic evaluation, age, gender, thyroid tissue and tumor diameter, presence of multifocality, laterality, microscopic features including vascular invasion, metastasis, lymph node count.

In addition to microscopic features demographic data were also collected for each patient. All parafin blocks were stained with HBME1, CITED1, PAX8, CD56. Table 1. shows the origin of antibodies, dilution, and the company names.

Nicon Eclipse E 600 light microscope including $\mathrm{x} 4, \mathrm{x} 20, \mathrm{x} 40, \mathrm{x} 100$ objectives and $\mathrm{x} 10$ ocular was used for microscopic evaluation. Level of cytoplasmic and/or cytoplasmic membrane expression for HBME1 and CD56; Level of nuclear and/or cytoplasmic expression for PAX8 and CITED1 was scored between 0-3. Expression with HBME 1 or CD56 <25\%, 25-50\%, >50\% were scored as 1-2-3 respectively. Expression with PAX8 and CITED I <25\%, 25-75\%, $>75 \%$ were scored as 1-2-3 respectively.

\section{Statistical Analysis}

SPSS software Ver.22 (SPSS Inc. Chicago, USA) was used for statistical analysis. Mean and standart deviation and median (minimum-maximum) was used for continious variables. The normality of data were evaluated with Kolmogorov-Smirnov test and Shapiro wilk test where suitable. Comparison of continious data were performed using Mann-Whitney U test and Independent Sample t test. Kruskall Wallis test was used for comparison of more than 2 groups. Post hoc comparisons were performed using Bonferroni correction. Categoric data were compared using Pearson Chi-square test. Fisher's exact test was used when expected value problem occurred. $\mathrm{P}<0.05$ was regarded as statistical significant.

\section{Results}

A total of 92 cases were encountered during the study period. The distrubution of the cases were as follows $22 \mathrm{NH}(23 \%), 14 \mathrm{FA}$ (15\%), 3 NIFTP (3\%), 3 WDC-NOS (3\%), 22 PC (23\%), 12 PCFV (13\%), 9 MIFC (9\%), 4
PDC (4\%), 3 AC (3\%). The mean age was $46.7 \pm 13.7$ years. The mean age was 42.7 in the PCs, which were the majority of our patients, and in the WDC-NOS was the lowest (37.3), while it was significantly higher in the AC (52.7) $(\mathrm{p}=0.02)$.

Seventy-five $(78.9 \%)$ of the cases were female and $20(21.1 \%)$ were male. When the patients with malignant and benign lesions were compared in terms of gender, there was no significant difference between these values as both benign and malignant cases were higher in women $(\mathrm{p}=0.669)$.

Extrathyroidal spread was noted in all cases of PC with lymph node metastasis. Vascular invasion was observed in $21.4 \%$ of malignant cases. Similarly, IHC expression was observed in the primary focus of thyroid and lymph nodes with PC metastasis in 5 patients there was no statistically significant difference $(\mathrm{p}=1.0)$.

Level of expression with HBME1 was significantly higher in malignant cases compared to benign group $(61.5 \%$ vs $0 \%$ for $<50 \%$ expression, $\mathrm{p}<0.001)$. Loss of CD56 expression was significantly higher in malignant group compared to benign cases $(78.9 \%$ vs $35 \%$ for $<10 \%$ expression $\mathrm{p}<0.001)$. CD56 expression in malignant cases was compared, MIFC showed significantly higher expression than other malignant cases $(p=0.00)$. There was no statistically significant difference between CD56 expression in FA and $\mathrm{NH}(\mathrm{p}=0.518)$. Cytoplasmic expression with PAX8 and CITED1 was similar between malignant and benign group. Nuclear expression with CITED1 was similar in benign and malignant cases. Nuclear expression with PAX8 was significantly higher in benign group compared to malignant group $(55 \%$ vs $14 \%, \mathrm{p}<0.05)$ (Table 2). When PAX8 cytoplasmic and nuclear expression prevalence of $\mathrm{FA}$ and $\mathrm{NH}$ were compared, no statistically significant difference was found between the groups ( $\mathrm{p}=$ $0.213)(\mathrm{p}=0.565)$.

The cytoplasmic expression of CITED1 was significantly higher in PC compared to other malignant tumors $(81.8 \%$, $\mathrm{p}<0.05)$. The expression of HBME1 in PC 
Table 1. Shows the origin of antibodies, dilution, and the company names.

\begin{tabular}{|c|c|c|c|c|c|}
\hline ANTIBODY & Clon & & Dilution & Control & Company \\
\hline CITED-1 & $\begin{array}{l}\text { Mouse } \\
\text { Antibody }\end{array}$ & Monoclonal & $7 \mathrm{ml}$ package & $\begin{array}{l}\text { Papillary thyroid } \\
\text { carcinoma }\end{array}$ & Thermo Scientific \\
\hline HBME-1 & $\begin{array}{l}\text { Mouse } \\
\text { Antibody }\end{array}$ & Monoclonal & $7 \mathrm{ml}$ package & $\begin{array}{l}\text { Papillary thyroid } \\
\text { carcinoma }\end{array}$ & Thermo Scientific \\
\hline PAX8 & $\begin{array}{l}\text { Mouse } \\
\text { Antibody }\end{array}$ & Monoclonal & $7 \mathrm{ml}$ package & Tonsillary & Thermo Scientific \\
\hline CD56 & $\begin{array}{l}\text { Mouse } \\
\text { Monoclon } \\
\text { (MOC-1) }\end{array}$ & al Antibody & $7 \mathrm{ml}$ package & $\begin{array}{l}\text { Neuroendocrine } \\
\text { carcinoma }\end{array}$ & Thermo Scientific \\
\hline
\end{tabular}

HBME1: Hector Battifora Mesothelial-1, CITED1: Cbp/p300 Interacting Transactivator, PAX8: Paired box-8

Table 2. Expression of CITED1, HBME1, PAX8 and CD56 in Malignant, Benign Thyroid Tumors

\begin{tabular}{|c|c|c|c|c|c|c|}
\hline & \multicolumn{3}{|c|}{ Cytoplasmic Staning } & \multicolumn{3}{|c|}{ Nuclear Staining } \\
\hline & Benign & Malignant & $\mathbf{P}$ & Benign & Malignant & $\mathbf{P}$ \\
\hline CITED-1 & & & 0,973 & & & 0,889 \\
\hline$<10$ & $5(13,9)$ & $6(11.5)$ & & $37(92.5)$ & $48(92.3)$ & \\
\hline $10-50$ & $9(22.5)$ & $13(25)$ & & $3(7.5)$ & $4(7,7)$ & \\
\hline$>50$ & $26(65)$ & $33(63,5)$ & & $0(0)$ & $1(1,9)$ & \\
\hline HBME-1 & & & $<0.001$ & NA & NA & \\
\hline$<10$ & $39(97.5)$ & $17(32.6)$ & & & & \\
\hline $10-50$ & $1(2.5)$ & $3(5.8)$ & & & & \\
\hline$>\mathbf{5 0}$ & $0(0)$ & $32(61.5)$ & & & & \\
\hline PAX-8 & & & 0,798 & & & 0,008 \\
\hline$<10$ & $3(7.5)$ & $5(9,6)$ & & $12(30)$ & $28(53.9)$ & \\
\hline $10-50$ & $5(12.5)$ & $10(19.2)$ & & $6(15)$ & $10(19.2)$ & \\
\hline$>\mathbf{5 0}$ & $32(80)$ & $37(71,2)$ & & $22(55)$ & $14(26.9)$ & \\
\hline CD56 & & & $<0.001$ & NA & NA & \\
\hline$<10$ & $14(35)$ & $41(78.9)$ & & & & \\
\hline $10-50$ & $7(17.5)$ & $6(11.5)$ & & & & \\
\hline$>\mathbf{5 0}$ & $19(47.5)$ & $5(9.6)$ & & & & \\
\hline
\end{tabular}

HBME1: Hector Battifora Mesothelial-1, CITED1: Cbp/p300 Interacting Transactivator, PAX8: Paired box-8 
Table 3. HBME1, CD56, CITED1 (Nuclear and Cytoplasmic Expression) and PAX8 (Nuclear and Cytoplasmic Expression) in all cases

\begin{tabular}{|c|c|c|c|c|c|c|c|c|c|c|c|}
\hline & $\begin{array}{l}\text { NH } \\
(\mathrm{n} \%)\end{array}$ & $\begin{array}{l}\text { FA } \\
(n \%)\end{array}$ & $\begin{array}{l}\text { NIFTP } \\
(\mathrm{n} \%)\end{array}$ & p & $\begin{array}{l}\text { PC } \\
(\mathrm{n} \%)\end{array}$ & $\begin{array}{l}\text { PCFV } \\
(\mathrm{n} \%)\end{array}$ & $\begin{array}{l}\text { MIIFC } \\
(\mathrm{n} \%)\end{array}$ & $\begin{array}{l}\text { WDCNO } \\
\text { S(n\%) }\end{array}$ & $\begin{array}{l}\text { PDC } \\
(\mathbf{n} \%)\end{array}$ & $\begin{array}{l}\mathrm{AC} \\
(\mathrm{n} \%)\end{array}$ & $\mathbf{p}$ \\
\hline CITEDl,c & & & & 0.201 & & & & & & & 0,00 \\
\hline$<10$ & $4(18.2)$ & $1(7.1)$ & $0(0)$ & & $1(4.5)$ & $2(16,6)$ & $2(22,2)$ & $1(33,3)$ & $1(25)$ & $1(33,3)$ & 3 \\
\hline $10-50$ & $4(18.2)$ & $5(35.7)$ & $0(0)$ & & $3(13,6)$ & $4(33,4)$ & $2(22,2)$ & $1(33,3)$ & $2(50)$ & $1(33,3)$ & \\
\hline$>50$ & $14(63.6$ & $8(57.1)$ & $3(100)$ & & $18(81,8$ & $6(50)$ & $5(55,6)$ & $1(33,3)$ & $1(25)$ & $1(33,3$ & \\
\hline CITEDln & & & & 0.161 & & & & & & & 0.18 \\
\hline$<10$ & $20(90.9$ & $14(100)$ & $2(66.7)$ & & $19(85.6$ & $11(90,9)$ & $8(88,9)$ & $3(100)$ & $4(100$ & $3(100)$ & 8 \\
\hline $10-50$ & $2(9.119$ & $0(0)$ & $1(33.3)$ & & $2(9,1)$ & $1(11,1)$ & $1(11,1)$ & $0(0)$ & $0(0)$ & $0(0)$ & \\
\hline$>50$ & $0(0)$ & $0(0)$ & $0(0)$ & & $1(4,5)$ & $0(0)$ & $0(0)$ & $0(0)$ & $0(0)$ & $0(0)$ & \\
\hline HBME1 & & & & NA & & & & & & & $<0$. \\
\hline$<10$ & $22(100)$ & $14(100)$ & $3(100)$ & & $O(0)$ & $0(0)$ & $8(88,9)$ & $2(66,7)$ & $4(100$ & $3(100)$ & 001 \\
\hline $10-50$ & & & & & $O(0)$ & $1(9.1)$ & $1(11,1)$ & $1(33,3)$ & $0(0)$ & $0(0)$ & \\
\hline$>50$ & & & & & $22(100)$ & $11(90.9)$ & $0(0)$ & $O(0)$ & $0(0)$ & $0(0)$ & \\
\hline PAX8,n & & & & 0.146 & & & & & & & 0,48 \\
\hline$<10$ & $7(31.8)$ & $5(35.7)$ & $0(0)$ & & $14(63.6$ & $7(58,4)$ & $8(88,9)$ & $3(100)$ & $4(100$ & $3(100)$ & 5 \\
\hline $10-50$ & $4(18.2)$ & $2(14.3)$ & $0(0)$ & & $7(31,8)$ & $2(16,6)$ & $0(0)$ & $0(0)$ & $0(0)$ & $0(0)$ & \\
\hline$>\mathbf{5 0}$ & $11(50)$ & $7(50)$ & $3(100)$ & & $1(4,5)$ & $3(25)$ & $1(11,1)$ & $0(0)$ & $0(0)$ & $0(0)$ & \\
\hline PAX8,n & & & & 0.574 & & & & & & & 0,00 \\
\hline$<10$ & $1(4.5)$ & $2(14.3)$ & $0(0)$ & & $1(4,5)$ & $2(16,7)$ & $0(0)$ & $1(33,3)$ & $1(25)$ & $0(0)$ & 7 \\
\hline $10-50$ & $3(13.6)$ & $2(14.3)$ & $0(0)$ & & $3(13,6)$ & $2(16,7)$ & $2(22,2)$ & $2(66,7)$ & $1(25)$ & $1(33,3)$ & \\
\hline$>50$ & $18(81.8$ & $10(71.4)$ & $3(100)$ & & $18(81,8$ & $8(66,6)$ & $7(77,8)$ & $0(0)$ & $2(50)$ & $2(66,7)$ & \\
\hline CD56 & & & & 0.060 & & & & & & & $<0$. \\
\hline$<10$ & $8(36.4)$ & $2(14.3)$ & $3(100)$ & & $21(95.5$ & $12(100)$ & $1(11,1)$ & $3(100)$ & $3(75)$ & $2(66,7)$ & 001 \\
\hline $10-50$ & $4(18.2)$ & $3(21.4)$ & $0(0)$ & & $1(4,5)$ & $0(0)$ & $3(33,3)$ & $0(0)$ & $1(25)$ & $1(33,3)$ & \\
\hline$>50$ & $10(45.5$ & $9(64.3)$ & $0(0)$ & & $0(0)$ & $0(0)$ & $5(55,6)$ & $0(0)$ & $0(0)$ & $0(0)$ & \\
\hline
\end{tabular}

PC: Papillary Carcinoma, PCFV: Papillary Carcinoma Folicular Variant, MIFC: Minimal Invasive Folicular Carcinoma, WDC-NOS: Well Differentiated Carcinoma, not other spesifite, PDC: Poorly Differentiated Carcinoma, AC: Anaplastic Carcinoma, HBME1 Hector Battifora Mesothelial-1, CITED1: Cbp/p300 Interacting Transactivator, PAX8: Paired box-8, c: cytoplasmic, n: nuclear

and PCFV was significantly higher compared to other malignant tumors (100\% and 90.9). Loss of CD56 expression was significantly higher in PC, WDC-NOS and PCFV compared to other malignant tumors $(\mathrm{p}<0.001)$. Cytoplasmic expression with PAX8 was higher in PC, PCFV, MIFC and AC compared to WDC-NOS and PDC (Table 3). WDC-NOS, PDC and AC showed nuclear expression $<10 \%$ with CITED1 and PAX8. The nuclear expression of CITED1 was not different between malignant cases. Only one case $(4.5 \%)$ showed nuclear expression $>50 \%$ with CITED1 in PC. Nuclear expression of PAX8 was not different between malignant cases (Table 3). All cases H\&E, HBME1, CITED1, PAX8, CD56 expression shows in picture $1,2,3,4,5$.

The sensitivity of CITED1 (cytoplasmic expression), PAX8 (cytoplasmic expression), HBME1 and loss of CD56 was $88 \%, 90 \%, 67 \%$, and $78 \%$ respectively in discriminating malignant and benign cases.
The specificity of CITED1 (cytoplasmic expression), PAX8 (cytoplasmic expression), HBME1 and loss of CD56 was $12.5 \%, 7 \%$, $97.5 \%$ and $65 \%$ respectively (Table 4.) The sensitivity of nuclear expression of CITED1 and PAX8 was $12 \%$ and $7 \%$ respectively for discriminating benign and malignant thyroid neoplasms. The specificity of nuclear expression CITED1 and PAX8 was $92 \%$ and $46 \%$ respectively. Positive predictive value of CITED1(cytoplasmic expression), PAX8 (cytoplasmic expression), HBME1 and loss of CD56 were 56\%, 56\%, 97.2\%, 74\% respectively. Diagnostic accuracy of HBME1 and loss of CD56 was significantly higher for PC and PCFV (area under curve>0.5) Figure shows sensitivity and specificity of the different markers in diagnosis of malignant thyroid tumors.

The performance of the various markers in the sensitivity of combination of the markers (HBME1, CITED1, PAX8, loss of CD56) in 


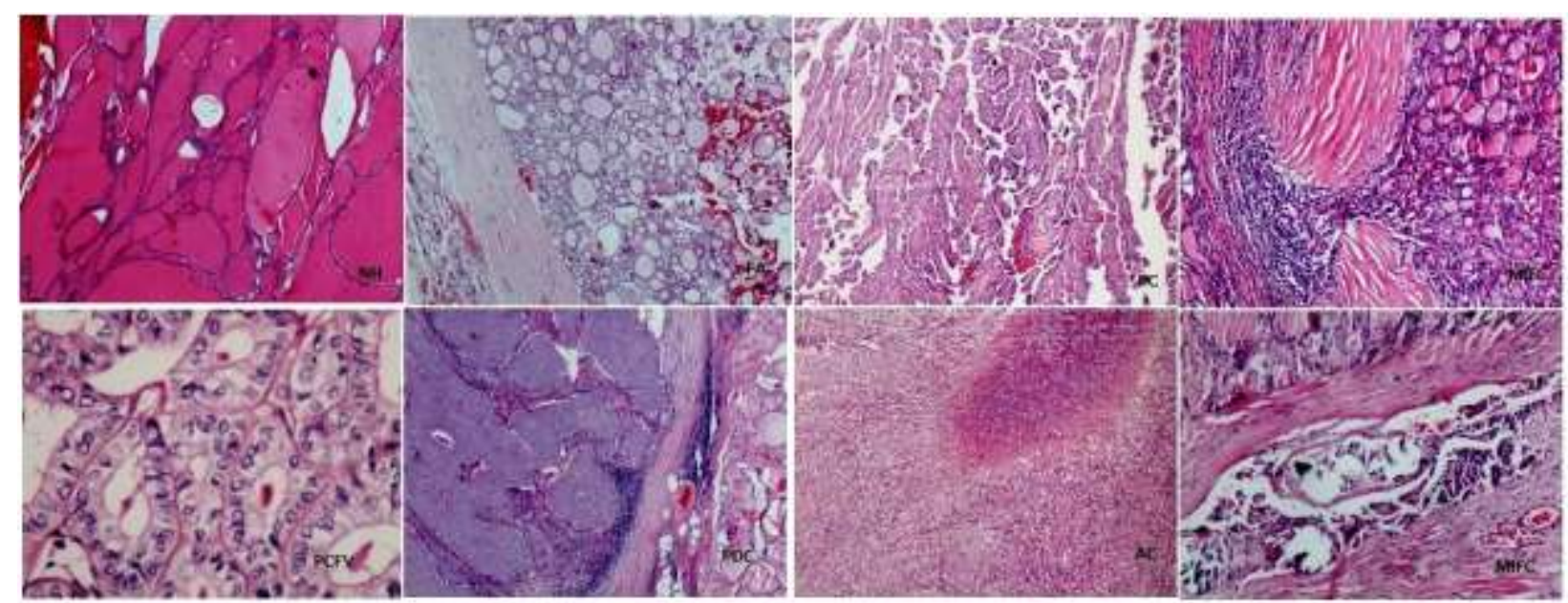

Picture 1: Hematoxylin eosin (H\&E) sections of PC (Papillary Carcinoma), PCFV (Papillary Carcinoma, Folicular Variant), MIFC (Minimal Invasive Folicular Carcinoma), PDC (Poorly Differentiated Carcinoma), AC (Anaplastic Carcinoma), FA (Folicular Adenoma), NH (Nodular Hyperplasia)
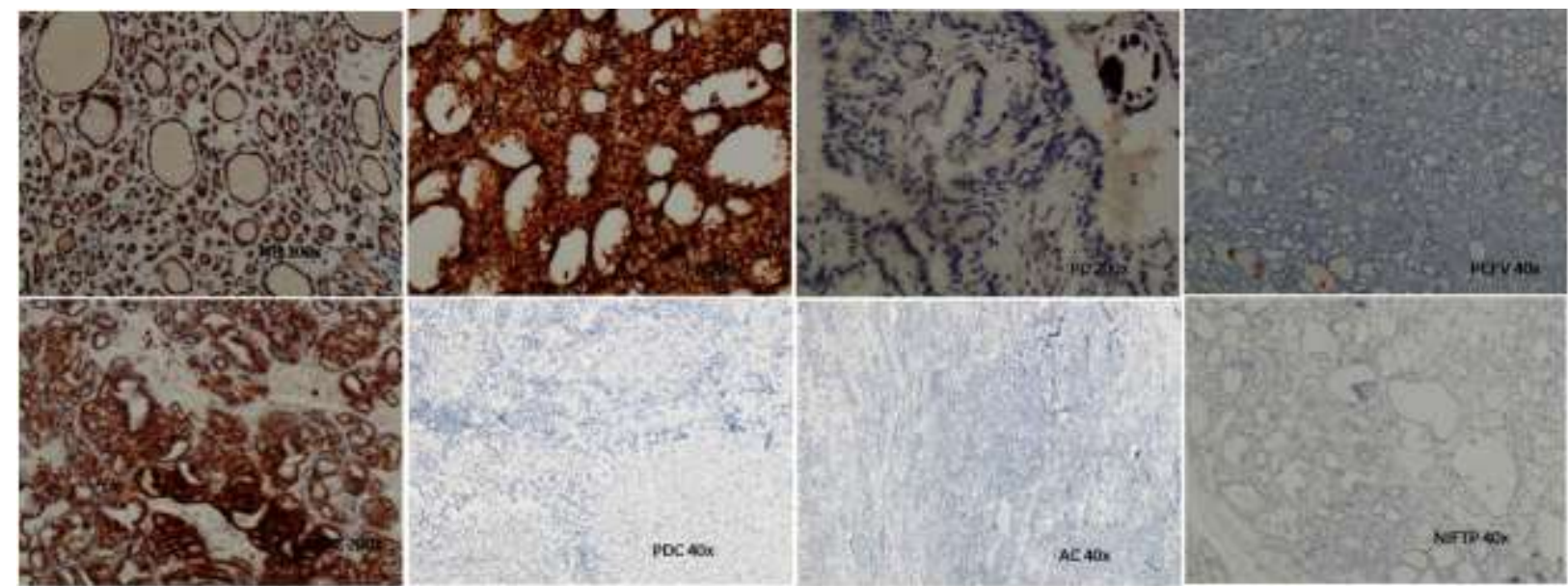

Picture 2: CD56 expression in Noduler Hyperplasia and Folicular Adenoma, MIFC (Minimal Invasive Folicular Carcinoma) loss of expression in the other malignant thyroid tumors
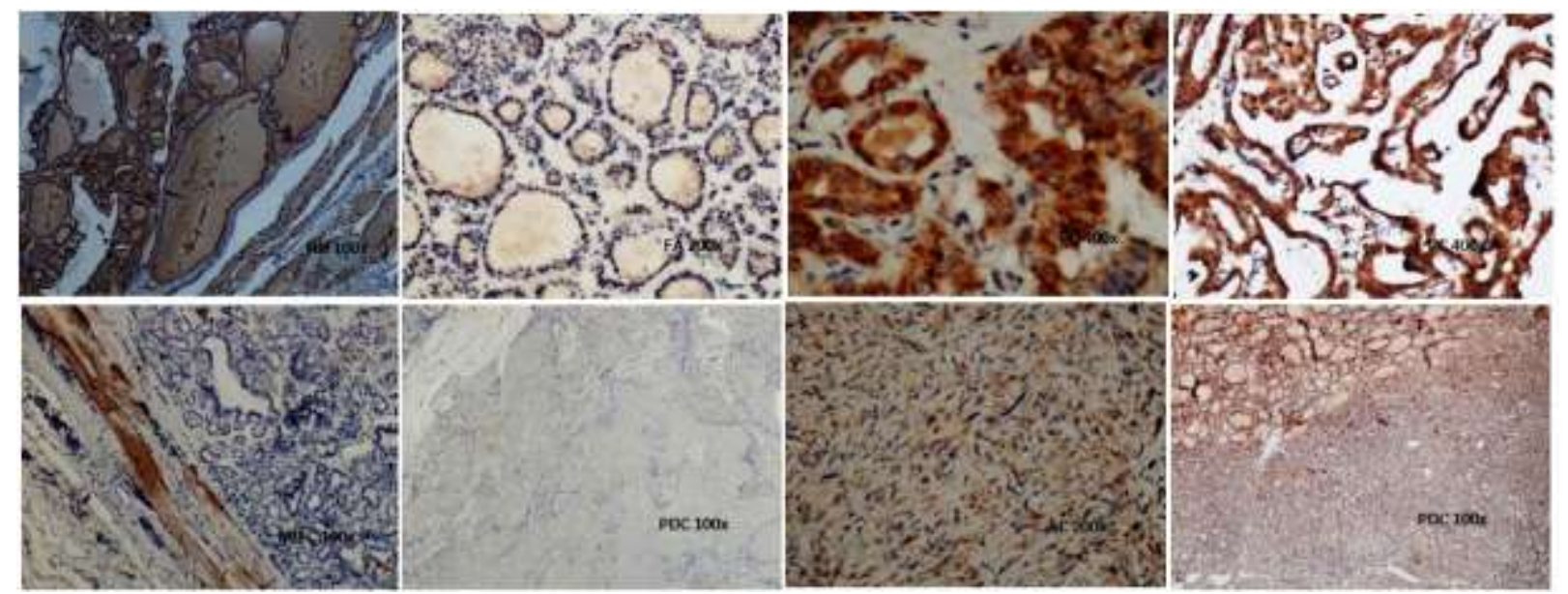

Picture 3: Widespread expression of CITED1 in Papillary Carcinoma and CITED1 expression in other neoplasm and Noduler Hyperplasia 

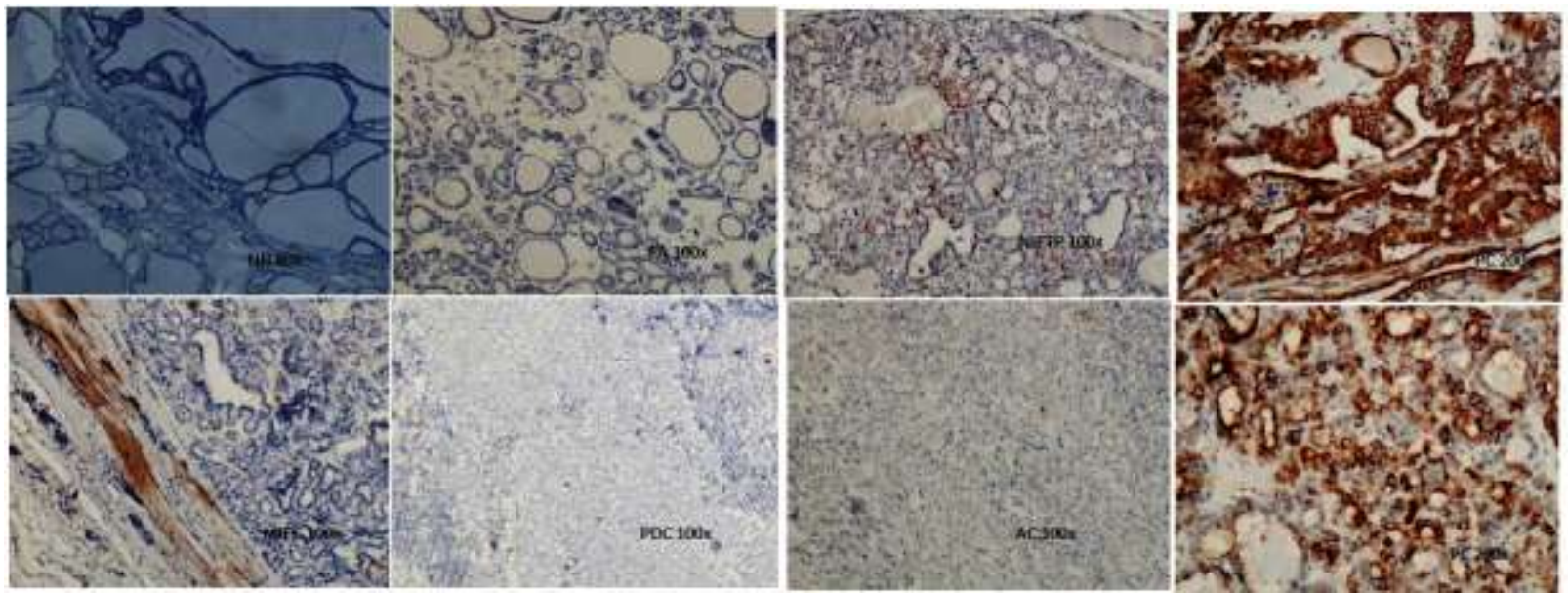

Picture 4: Widespread expression of HBME1 in Papillary Carcinoma, Papillary Carcinoma Folicular varyant and lack of expression in other neoplasm and Noduler Hyperplasia

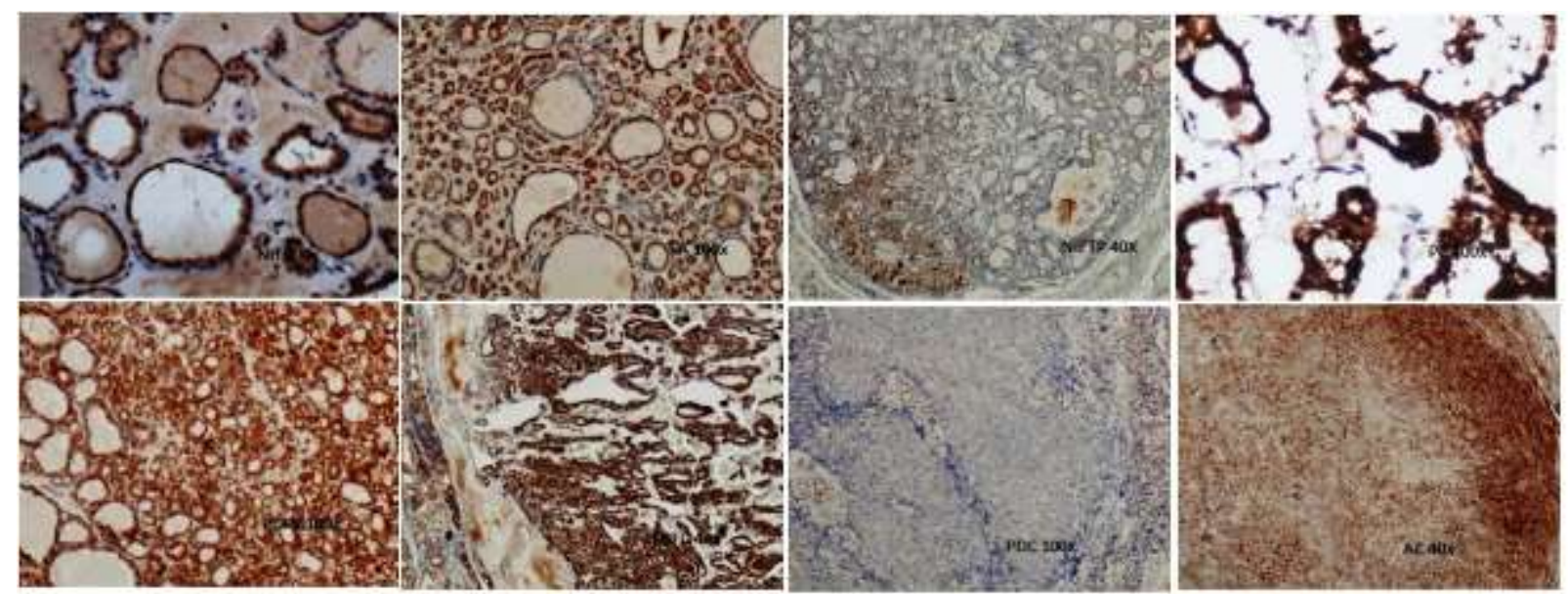

Picture 5: PAX8 expression in malignant and benign neoplasm and also Nodular Hyperplasia

Table 5. Sensitivity, specificity, positive predictive values, negative predictive values of Immun markers combination for differantiating benign cases from malignant tumors and sensitivity, specificity, positive predictive values, negative predictive values of ımmun markers combination for differantiating papillary carcinoma from the other malignant thyroid tumors

\begin{tabular}{|c|c|c|c|c|c|c|c|c|c|c|c|c|}
\hline & \multicolumn{6}{|c|}{ Differentiating papillary carcinoma from the other malignant thyroid } & \multicolumn{6}{|c|}{ Differentiating benign cases from malignant tumors } \\
\hline & HBMEI & HBMEl & PAX8 & CITED1 & PAX8 & HBME1 & HBME1 & HBME1 & PAXS & CITED1 & PAX8 & HBMEl \\
\hline & CD56(-) & CITED 1 & $\operatorname{CD} 56(-)$ & CD56(-) & CITED1 & PAXS & CD56(-) & CMED1 & $\operatorname{cD} 56(-)$ & $\operatorname{CD} 56(-)$ & CITED1 & PAXS \\
\hline SENSITIVITY (\%) & 100 & 94,6 & 100 & 100 & 97,3 & 100 & 83,9 & 69,6 & 100 & 100 & 94,6 & 98,2 \\
\hline SPECIFICITY (\%) & 60,3 & 86,2 & 5,2 & 3,4 & 6,9 & 5,2 & 72,2 & 91,7 & 8,3 & 5,6 & 8,3 & 8,3 \\
\hline PPV (\%) & 61,7 & 81,4 & 40,2 & 39,8 & 40 & 40,2 & 82,5 & 92,9 & 62,9 & 62,2 & 61,6 & 62,5 \\
\hline NPV $(\%)$ & 100 & 96,2 & 100 & 100 & 80 & 100 & 74,3 & 66 & 100 & 100 & 50 & 75 \\
\hline
\end{tabular}



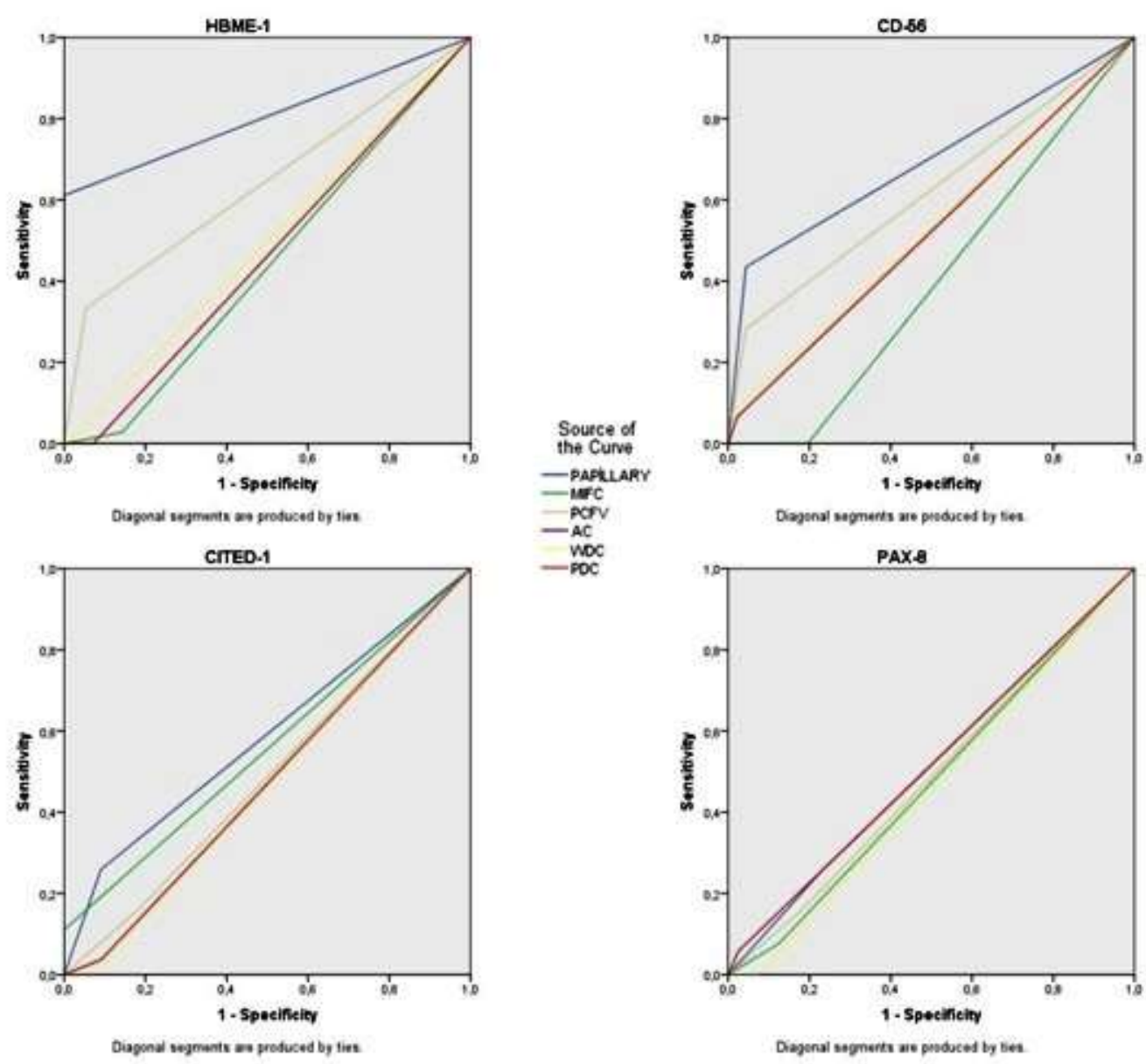

Figure 1. Shows sensitivity and specificity of the different immun markers in diagnosis of malignant thyroid tumors

discriminating benign and malignant cases was $100 \%$ however the specificity was low $(8.3 \%)$. The specificity of PAX8 was extremely low that the combination of markers with PAX8 decreased the specificity (Table 5).

The combination of HBME1 and loss of CD56 showed $100 \%$ sensitivity and $60.3 \%$ specificity for PC. The combination of HBME1 and CITED1 the sensitivity and specificity were $94,6 \%$ and $86,2 \%$ respectively for PC (Table 5).

\section{Discussion}

Discrimination of benign and malignant thyroid tumors based on only morphologic evaluation may be insufficient. Additional immunhistochemical markers may be needed in cases of similar morphological findings.
This study evaluated use of HBME1, PAX8, CD56 and CITED1 in discrimination of benign lesions and malignant thyroid tumors. The most sensitive markers were PAX8 (cytoplasmic expression), and CITED1 (cytoplasmic expression) in discriminating benign lesions and malignant thyroid tumors. However the specificity was lower relatively. The most specific markers were HBME1 expression in discriminating benign lesions and malignant thyroid tumors.

HBME1 was reported to be useful in discrimination of malignant thyroid tumors [6]. The combination of HBME1, GAL-3, CK19 discrimination of FA and PCFV [6]. The sensitivity and specificity of HBME1 in detecting PC was found to be $87 \%$ and $96 \%$ respectively [7]. In the current study expression with HBME1 in PC and PCFV 
patients was significantly higher compared to other malignant thyroid tumors.

HBME1 was also found to be the most sensitive marker for PC [8]. On the other hand the specificity was reported to be low in diagnosis of PC by the study conducted by Cheung et. al [9]. Similarly our findings supported the literature that HBME1 specificity was significantly higher in PC.

The expression of HBME1 in MIFC and $\mathrm{AC}$ was relatively low compared to other histologic subtypes. Similarly Atik et. al found that none of the MIFC showed expression with HBME1 [10]. In the current study although sensitivity was low HBME1 positivity was highly specific marker for malignancy. As our study included all types of thyroid malignancies like MIFC and AC the low level of sensitivity may be attributable to low expression of these rare types of malignant thyroid tumors.

Generally cytoplasmic and nuclear expression of CITED1 was regarded as positive in literature $[3,11]$. However some of the studies regarded only cytoplasmic positivity for CITED1 [12]. In the current study we evaluated cytoplasmic and nuclear CITED1 expression.

CITED1 was reported to show increased expression in PC [13]. CITED1 expression was observed in 87-100\% PC [14]. Since expression of CITED1 was not shown in normal thyroid tissue the marker was proposed to be a useful in discriminitation of benign and malignant thyroid tumors [7]. In the current study cytoplasmic expression of CITED1 was found to be highly specific PC compared to other malignant thyroid tumors.

The expression of CITED1 was not shown in AC [12]. In the current study the expression of CITED1 in AC was relatively high.

PAX8-PPAR $\gamma$ gene fusion was shown in FC [15]. PAX8-PPAR $\gamma$ gene fusion was reported to be specific for FC compared to FA, $\mathrm{PC}$ and $\mathrm{NH}$ [15]. PAX8-PPAR $\gamma$ gene fusion was shown to be responsible in the patogenesis of FC [16]. In addition up to $70 \%$ of FC cases was shown to express PAX8 positivity [17]. Lacroix et al. reported that translocation of PAX8-PPAR $\gamma$ could effect occurence of FC however was not specific for carcinoma and immunhistochemistry was not a reliable marker for detection of translocation of PAX8-PPAR $\gamma$ [18]. We observed high level of expression with PAX8 in FC and the other malignant thyroid tumors. They were also showed similar expression with PAX8 except for WDC-NOS. As a result PAX8 was not a specific marker for FC.

Although nuclear expression of PAX8 is accepted, in some markers for example Ki67 is normally a nuclear staning marker, while cytoplasmic staining in hyalinized trabecular tumor of thyroid [19]. For this reason, we wanted to share our experience on this subject, thinking that it might be meaninful in terms of directing future studies.

Loss of CD56 expression was reported to be a good marker for discriminating benign and malignant cases and decreased expression was shown for PC in the literature [4]. The sensitivity and specificity was reported to be as high as $100 \%$ by some authors [20]. Loss of CD56 expression was above 95\% in PC, PCFV and MIFC in our study. Ozolins et al. reported the loss of expression CD56 in PC compared to normal thyroid tissue [21].

Since none of the marker has $100 \%$ sensitivity and specificity. The combination of the markers may increase sensitivity and specificity. The combination of the markers were shown to be useful by several authors. [22-24].

Nechifor-Boila et al, CD56, CK19, Galektin3 and HBME1 markers which were used together in PC, PCFV, Thyroid Tumors of Uncertain Malignant Potential, found that sensitivity was increased [23]. The combination of HBME1, Galektin3, CK19 and HBME1, CITED1, Galektin3 was shown to be the most efficient combination for discrimination of FC and PCFV [24].

Abd El Atti et al. evaluated the expression of CD56 and Claudin 1 in benign, malignant neoplasms and nonneoplastic thyroid tissue of the thyroid. 5 out of 10 Thyroid Tumors Of Uncertain Malignant Potential were diagnosed with PC when combined with loss of CD56 and Claudin1. As 
a result, when immunohistochemical markers such as loss of CD56 and Claudin1 were evaluated together, it was concluded that they could be used to separate PCFV from nodules in the folicular patern [22].

In our study, when HBME1, loss of CD56 expression were used together, to discriminating benign and malignant cases the sensitivity was $83.9 \%$, specificity $72.2 \%$ and specificity was higher that when HBME1 was used alone. When HBME1, loss of CD56 expression were used together, to discriminating PC and the other malignant tumors the sensitivity was $100 \%$, specificity $60.3 \%$ and specificity (91.9) was higher that when HBME1 was used alone but the sensitivity $(60.3 \%)$ was lower that when HBME1 was used alone. HBME1 and CITED1 expression were used together the sensitivity was $94.6 \%$ and the specificity was $86.2 \%$. Although it was observed that sensitivity increased up to $100 \%$ in other combinations of markers but specificity was

\section{REFERENCES}

1. Basu S, Nair N, Borges AM. Aggressive behaviour of solid arrangement pattern in differentiated papillary carcinoma of thyroid. JournalAssociation of Physicians of India. 2003; 51: 408-11.

2. Rossi E, Raffaelli M, Mule' A, Miraglia A, Lombardi CP, Vecchio FM, et al. Simultaneous immunohistochemical expression of HBME-1 and galectin-3 differentiates papillary carcinomas from hyperfunctioning lesions of the thyroid. Histopathology. 2006; 48(7): 795-800.

3. Prasad ML, Pellegata NS, Kloos RT, Barbacioru C, Huang Y, de la Chapelle AJT. CITED1 protein expression suggests papillary thyroid carcinoma in high throughput tissue microarray-based study. Thyroid. 2004; 14(3): 169-75.

4. El Demellawy D, Nasr AL, Babay S, Alowami S. Diagnostic utility of CD56 immunohistochemistry in papillary carcinoma of the thyroid. PathologyResearch and Practice. 2009; 205(5): 303-9.

5. Kroll TG, Sarraf P, Pecciarini L, Chen C-J, Mueller E, Spiegelman BM, et al. PAX8-PPARY1 fusion in oncogene human thyroid carcinoma. Science. 2000; 289(5483):1357-60. very low. While our results were compatible with some of the results stated in the literature, some of them were not.

In addition that the use of immunohistochemical markers in confirming the diagnosis of tumor in preoperative cytological materials is increasingly common [25]. Indicating that these markers can also be useful in cytological diagnosis.

Conclusions: Cytoplasmic expression of CITED1 was found to be highly specific PC compared to other malignant thyroid tumors. Nuclear expression of PAX8 was significantly higher in benign cases compared to malignant tumors. HBME1 was the most specific marker in discriminating malignant and benign cases. HBME1 and loss of CD56 was an both sensititive and specific markers for PC. The best combination to distinguish PC from the other malignant thyroid tumors was HBME1 and loss of CD56, HBME1 and CITED1 (cytoplasmic expression).

6. Saggiorato E, De Pompa R, Volante M, Cappia $\mathrm{S}$, Arecco F, Dei Tos A, et al. Characterization of thyroid 'follicular neoplasms' in fine-needle aspiration cytological specimens using a panel of immunohistochemical markers: a proposal for clinical application. Endocrine-related cancer. 2005; 12(2): 305-17.

7. Carpi A, Mechanick JI, Saussez S, Nicolini A. Thyroid tumor marker genomics and proteomics: diagnostic and clinical implications. Journal of cellular physiology. 2010; 224(3): 612-9.

8. Alexander EK, Kennedy GC, Baloch ZW, Cibas ES, Chudova D, Diggans J, et al. Preoperative diagnosis of benign thyroid nodules with indeterminate cytology. New England Journal of Medicine. 2012; 367(8): 705-15.

9. Cheung CC, Ezzat S, Freeman JL, Rosen IB, Asa SLMp. Immunohistochemical diagnosis of papillary thyroid carcinoma.Modern Pathology. 2001; 14(4): 338-42.

10. Atik E, Guray M, Gunesacar R, Ozgur T, Canda T. Immunohistochemical analysis of thyroid follicular neoplasms and BRAF mutation correlation. Indian journal of cancer. 2014;51(1):63.

11. Scognamiglio T, Hyjek E, Kao J, Chen Y-T. Diagnostic usefulness of HBME1, galectin-3, CK19, and 
CITED1 and evaluation of their expression in encapsulated lesions with questionable features of papillary thyroid carcinoma. American Journal of Clinical Pathology. 2006; 126(5):700-8.

12. Liu YY, Morreau H, Kievit J, Romijn JA, Carrasco N, Smit JWJEJoE. Combined immunostaining with galectin-3, fibronectin-1, CITED-1, Hector Battifora mesothelial-1, cytokeratin-19, peroxisome proliferator-activated receptor- $\psi$, and sodium/iodide symporter antibodies for the differential diagnosis of non-medullary thyroid carcinoma. European Journal of Endocrinology. 2008; 158(3):375-84.

13. Fischer S, Asa SL. Application of immunohistochemistry to thyroid neoplasms. Archives of pathology \& laboratory medicine. 2008;132(3):35972.

14. Prasad ML, Pellegata NS, Huang $Y$, Nagaraja HN, de la Chapelle A, Kloos RT. Galectin-3, fibronectin1, CITED-1, HBME1 and cytokeratin-19 immunohistochemistry is useful for the differential diagnosis of thyroid tumors. Modern Pathology. 2005; 18(1): 48.

15. Marques AR, Espadinha C, Catarino AL, Moniz Sn, Pereira T, Sobrinho LsG, et al. Expression of PAX8PPARY1 rearrangements in both follicular thyroid carcinomas and adenomas. The Journal of Clinical Endocrinology \& Metabolism. 2002; 87(8): 3947-52.

16. Eberhardt NL, Grebe SK, Mclver B, Reddi HV. The role of the PAX8/PPARy fusion oncogene in the pathogenesis of follicular thyroid cancer. Molecular and cellular endocrinology. 2010; 321(1): 50-6.

17. Mclver B, Grebe SK, Eberhardt NL. The PAX8/PPARY fusion oncogene as a potential therapeutic target in follicular thyroid carcinoma. Current Drug Targets-Immune, Endocrine \& Metabolic Disorders. 2004; 4(3): 221-34.

18. Lacroix L, Mian C, Barrier T, Talbot M, Caillou $B$, Schlumberger $M$, et al. PAX8 and peroxisome proliferator-activated receptor gamma 1 gene expression status in benign and malignant thyroid tissues. European Journal of Endocrinology. 2004; 151(3): 367-74.

19. Lenggenhager D, Maggio EM, Moch H, Rössle MJH. HBME-1 expression in hyalinizing trabecular tumours of the thyroid gland. Histopathology. 2013; 62(7): 1092-7.

20. Nechifor-Boila A, Borda A, Sassolas G, HafdiNejjari Z, Borson-Chazot F, Lifante JC, et al. Immunohistochemical markers in the diagnosis of papillary thyroid carcinomas: The promising role of combined immunostaining using HBME-1 and CD56. Pathology-Research and Practice. 2013;209(9):585-92. 21. Ozolins A, Narbuts Z, Strumfa I, Volanska G, Stepanovs K, Gardovskis J. Immunohistochemical expression of HBME-1, E-cadherin, and CD56 in the differential diagnosis of thyroid nodules. Medicina. 2012; 48(10):74.

22. Abd El Atti RM, Shash LS. Potential diagnostic utility of CD56 and claudin-1 in papillary thyroid carcinoma and solitary follicular thyroid nodules. Journal of the Egyptian National Cancer Institute. 2012; 24(4):175-84.

23. Nechifor-Boila A, Catana R, Loghin A, Radu TG, Borda A. Diagnostic value of HBME-1, CD56, Galectin3 and Cytokeratin-19 in papillary thyroid carcinomas and thyroid tumors of uncertain malignant potential. Romanian Journal of Morphology \& Embryology. 2014; 55(1):49-56.

24. Nakamura N, Erickson LA, Jin L, Kajita S, Zhang $H$, Qian $X$, et al. Immunohistochemical separation of follicular variant of papillary thyroid carcinoma from follicular adenoma. Endocrine Pathology. 2006; 17(3): 213-23.

25. Trimboli P, Guidobaldi L, Amendola S, Nasrollah N, Romanelli F, Attanasio D, et al. Galectin-3 and HBME-1 improve the accuracy of core biopsy in indeterminate thyroid nodules. Endocrine. 2016; 52(1): 39-45.

Corresponding author e-mail: gamzecirak@gmail.com

Orcid ID:

Gamze Erkılınç 0000-0003-4704-7415

Sezer Kulaçoğlu 0000-0003-3288-2039

Doi: $10.5505 /$ aot.2021.26818 